\title{
Effect of Salicylic Acid on Alleviating of Electrolyte Leakage and Flower Organ Damage in Apricot (Prunus armeniaca L. cv. 'Shahroudi') under Artificial Cold Stress
}

\author{
Morteza ALIREZAIE NOGHONDAR*, Hassan BAYAT, Hossein NEAMATI \\ Ferdowsi University of Mashhad, Faculty of Agriculture, Department of Horticulture, Mashhad, Iran; mortezaalirezaie@yahoo.com
}

\begin{abstract}
One of the most important limiting factors in spread of apricot in Iran is late spring frost, which damages flower bud and decrease total yield of crop. It has been found that salicylic acid (SA) plays a beneficial role during plant response to chilling and freezing stresses. To evaluate the effects of salicylic acid on alleviating of cold stress, the flower buds (FBs) of Prunus armeniaca L. cv. 'Shahroudi' were sprayed at pink cluster stage with SA at 4 levels $(0,0.5,1$ and $2 \mathrm{mM})$ and were then exposed to artificial cold stress $\left(4 \mathrm{~h}\right.$ at $\left.-4^{\circ} \mathrm{C}\right)$ or without cold stress (+25). Experimental attributes including electrolyte leakage of FBs and percentage of damage (PD) of pistil, anthers and petals to temperature treatments were determined. The results showed that at $-4^{\circ} \mathrm{C}$ the lowest and highest PD and EL of FBs were observed in application of 0.5 and $0 \mathrm{mM} \mathrm{SA}$, respectively. The highest and lowest PD of flower organ and EL were obtained in application of 0 and $2 \mathrm{mM} \mathrm{SA}$, respectively at $+25^{\circ} \mathrm{C}$. Based on the results of this experiment, SA alleviates the negative effect of cold stress on electrolyte leakage and flower organ damages in apricot cv. 'Shahroudi', depending on the concentrations of SA used.
\end{abstract}

Keywords: electrolyte leakage, pink cluster, salicylic acid, stress

\section{Introduction}

The Prunus armeniaca L., belonging to the family Rosaceae, genus Prunus L., the subgenus Prunophora Focke, and the section Armeniaca, is one of the most cultivated stone fruits in the world (Ercisli, 2009; Hurtado et al., 2002; Rehder, 1967; Vilanova et al., 2003). It has been domesticated in the wide area covering, Iran, Turkistan, Afghanistan, Middle Asia and Western China, over 5,000 years ago (Faust et al., 1998). Total production of fresh apricot in the world is between 2.2 and 2.7 million tons per year. Because of its suitable climatic conditions, Iran is one of the major centers of apricot production ranking second in the world, and accounting for 12.7 percent of world apricot production (Ercisli, 2009).

Apricot tree is known as an early blooming and sensitive to frost. One of the main problems of apricot production in Iran, especially in Mashhad is the irregular and fluctuating production rates. For many years the apricot production of Iran has been unregulated because of late spring frost. This is the result of early flowering of native genotypes and coincidence of their flowering times with a cold spring. Late flowering is considered important to avoid disastrous spring frost damage (Tsonev, 1995). In breeding programs, one of the objectives is to produce varieties which flower so late that all dangers practically to the blossoms from late frost are past. Another contributory factor to the crop loss due to late frost is the inherent susceptibility of the flowers to injury (Hodun et al., 2002; Lin and Pliszka, 2001; Tsonev, 1995).

Growth regulators and chemical treatments sometimes cause higher resistance to cold of different parts of plants. Potassium nitrate in apricot has been reported to be effective in reducing the adverse effects of cold stress (Ozturk et al., 2006). Abscisic acid (ABA) treatment (1-4 mol) caused increase in the cold resistance of Cornus stolontifera about 2 degrees (Fuchigami et al., 1971). Also, control of flowering time in apricot and other stone fruits by application of growth regulators such as ethephon and gibberellic acid have been studied by other researchers (Durner and Gianfagna, 1988; Ganji Moghadam and Mokhtarian, 2006; Gianfagna, 1988; Murdoc and Ferguson, 1990; Soni and Yousif, 1978).

Salicylic acid (SA), a natural plant hormone, has various effects on the tolerance to abiotic stress as well as the regulation of plant growth and development (Bergmann et al., 1994; Raskin, 1992; Van Breusegem et al., 2001). During recent years, SA has received particular attention because of its role in modulating plant response to several abiotic stresses, such as chilling, heat, drought, salt and ultraviolet radiation. Studies show that SA increases chilling tolerance of wheat (Tasgin et al., 2003), maize (Janda et al., 1999; Kang and Saltveit, 2002), tomato (Ding et al., 2002; Senaratna et al., 2000), peach (Cao et al., 2010; Wang et al., 2006), pomegranate (Sayyari et al., 2009), apricot (Guo et al., 2007), anthurium (Promyoua et al., 
2012), banana (Kang et al., 2003), bean (Senaratna et al., 2000), rice and cucumber (Kang and Saltveit, 2002).

The apricot trees, under Noghondar climatic conditions, because of early blooming in spring, are often injured by late frost, and losing the yield lost by frost at blooming period is $30-40 \%$ almost every year, or sometimes there will be no production at all. This problem has not been solved effectively. Therefore, the aim of this study was to evaluate whether apricot flowers (cv. 'Shahroudi') would response favorably to $\mathrm{SA}$ under artificial cold stress.

\section{Material and methods}

This experiment was conducted at agricultural college of Ferdowsi university of Mashhad, Iran in 2012. In this study, the apricot, suitable for fresh market, which is widely cultivated in Noghondar region around Mashhad -North east of Iran- (36 $22^{\prime}$ latitude and $59^{\circ} 17^{\prime}$ longitude), was selected. Three trees were selected and live flower buds at pink cluster stage were randomly collected from all quadrants of the trees. Each experimental unit consists of four branches ( 15 - $20 \mathrm{~cm}$ long) of one-year-old fruiting shoots. Each one contains ten buds, i.e. 40 buds for each treatment in four SA concentration treatments $(0,0.5,1$ and $2 \mathrm{mM}$. $\mathrm{L}^{-1}$ as spray application) and two thermal levels, including artificial cold stress $\left(-4^{\circ} \mathrm{C}\right)$ or without cold stress $\left(+25^{\circ} \mathrm{C}\right)$ was studied. The all above branches were pretreated by spraying flower buds with SA $\left(0,0.5,1\right.$ and $\left.2 \mathrm{mM} . \mathrm{L}^{-1}\right) 1$ $\mathrm{d}$ before artificial cold stress treatment. The artificial cold stress treatment was performed on half of branches, which were kept in a freezing chamber and exposed at a temperature of $-4^{\circ} \mathrm{C}$ and $75 \%$ relative humidity in the dark (for 3 h) achieved by a continuous chilling decrease $\left(2^{\circ} \mathrm{C} \mathrm{h}^{-1}\right)$. Then, they were evaluated carefully for observed chilling injuries. The other half of the branches, which were pretreated by SA, were kept at a temperature of $25^{\circ} \mathrm{C}$ and $75 \%$ relative humidity in the dark. The experiment was factorial based on a completely randomized design with 40 buds per replication. To assess specific symptoms of flower abnormalities such as the browning of tissues affecting pistils, stamens or petals, samples of buds (40, arranged as four replications) were bisected longitudinally and observed under a stereo-microscope (Nikon HFX-II). Data expressed as percentages.

In the second stage, the Electrolyte leakage was evaluated (EL) by Barranco et al. (2005), method. $0.5 \mathrm{~g}$ fresh weight of the flowers were excised and placed in Erlenmeyer flask containing $20 \mathrm{~mL}$ distilled $\mathrm{H}_{2} \mathrm{O}$ and incubated for $24 \mathrm{~h}$ in a shaker at $23^{\circ} \mathrm{C}$ under continuous light. The initial electrolyte conductivity $\left(\mathrm{EC}_{1}\right)$ of each sample was measured to obtain an indirect indication of the amount of ion released at each treatment. Then, the same samples were placed in an autoclave at $121^{\circ} \mathrm{C}$ for $20 \mathrm{~min}$ and a second reading $\left(\mathrm{EC}_{2}\right)$ was recorded after cooling the solution to room temperature. The EL was calculated as $\mathrm{EC}_{1} / \mathrm{EC}_{2}$ and expressed as percent.
The statistical analysis was performed using Microsoft Excel (2007) and MSTAT C software and means were compared using Duncan's Multiple Range Test (DMRT) at $\alpha=0.05$.

\section{Results}

As it's shown in Tab. 1 , at $-4^{\circ} \mathrm{C}$ and no SA application $(0 \mathrm{mM})$ the highest damage of flower organs was observed (27.2, 33.57 and 66.88 percent for petals, anthers and pistils, respectively) ( $p \leq 0.05)$. The lowest damage symptoms was observed under $-4^{\circ} \mathrm{C}$ in application of $0.5 \mathrm{mM}$ SA $(7.11,8.65$ and 10.83 percent for petals, anthers and pistils, respectively), but increasing $\mathrm{SA}$ concentrations from 0.5 to $2 \mathrm{mM}$ gradually caused slight increase in damage. No significant difference was observed between 0.5 and $1 \mathrm{mM}$ concentrations. At $25^{\circ} \mathrm{C}$, the highest and lowest symptoms of damage to flower organs were obtained in application of 0 and $2 \mathrm{mM} \mathrm{SA}$, respectively $(p \leq 0.05)$. Among different flower organs, the highest and lowest symptoms of damage were observed in pistils and petals in all treatments, respectively. Damaged organs ranged from brown to yellow-brown which are distinctive morphological sign of chilling injury. Fig. 1 and 2 show intact and damaged pistils in 0 and $0.5 \mathrm{mM}$ SA pretreatment under artificial cold stress treatment $\left(-4^{\circ} \mathrm{C}\right)$.

At $-4^{\circ} \mathrm{C}$, the highest and lowest EL of flower buds (FBs) were obtained in application of 0 and $0.5 \mathrm{mM}$ of $\mathrm{SA}$, respectively (Fig. 3). Under $25^{\circ} \mathrm{C}$, the highest and lowest EL

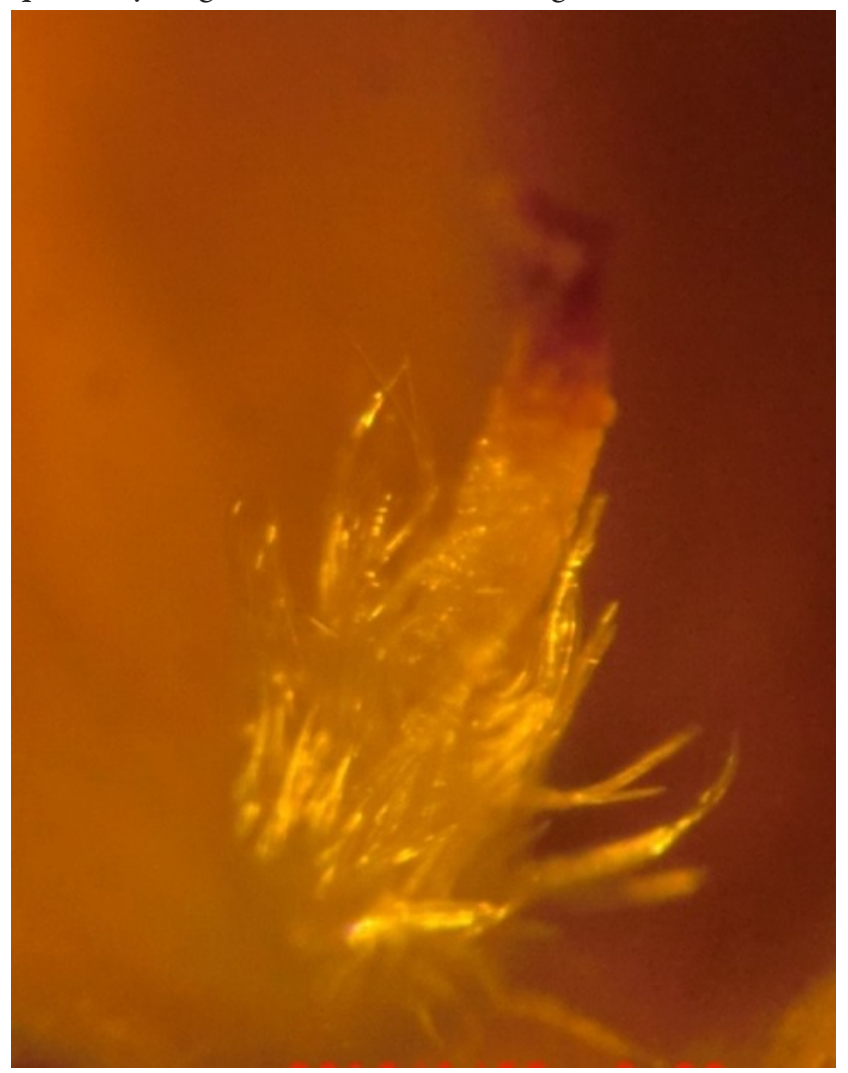

Fig. 1. Damaged pistil ( $0 \mathrm{mM} \mathrm{SA}$ and $-4^{\circ} \mathrm{C}$ artificial cold stress $)$ 
64

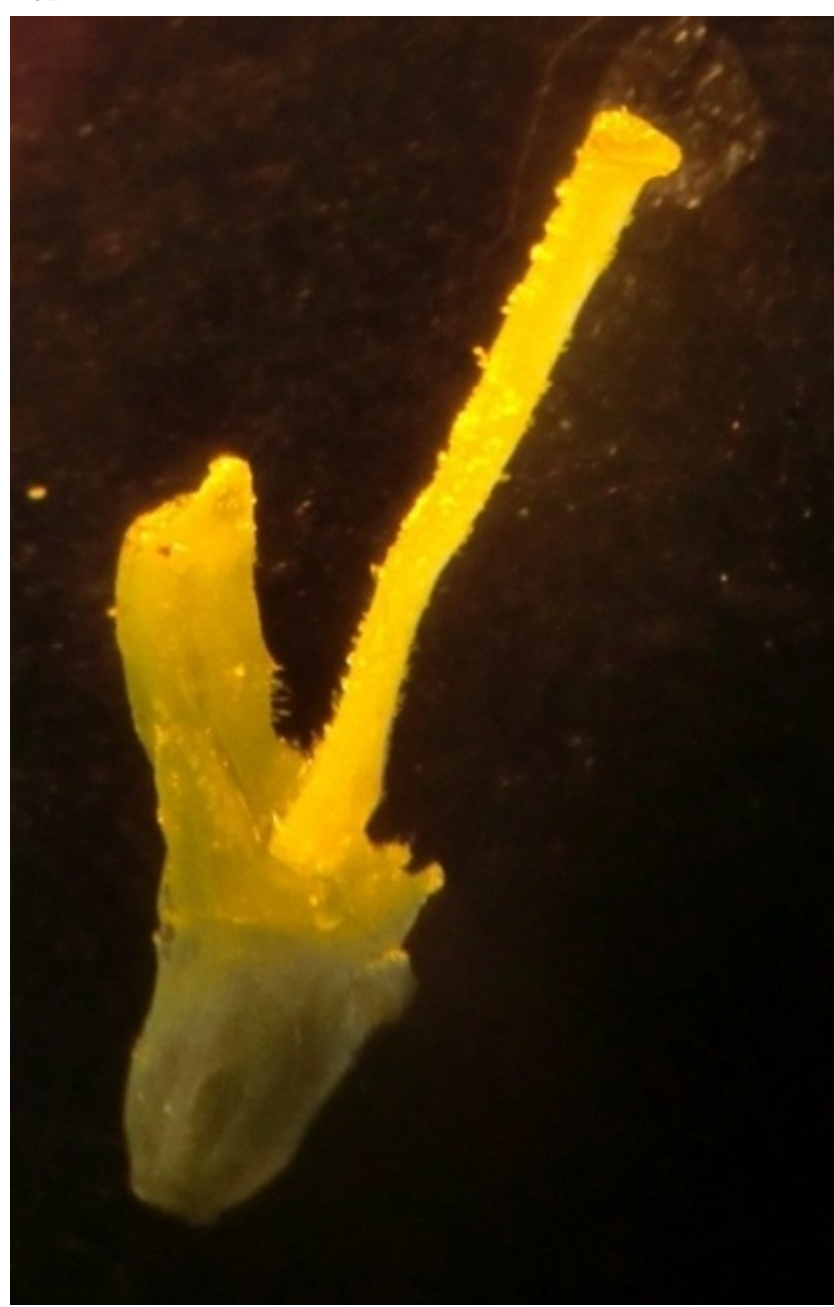

Fig. 2. Intact pistil ( $0.5 \mathrm{mM} \mathrm{SA}$ and $-4^{\circ} \mathrm{C}$ artificial cold stress)

of FBs were observed at 0 and $2 \mathrm{mM}$ of SA, respectively. With increasing of SA concentration from 0.5 to $2 \mathrm{mM}$, EL was increased at both temperature treatments (Fig. 3).

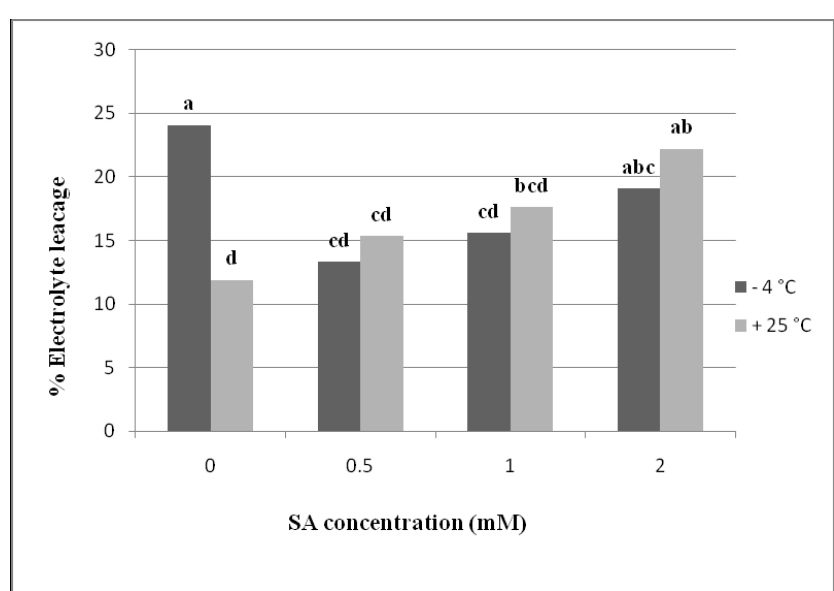

Fig. 3. Effect of exogenous SA pretreatment $(0,0.5,1$ and 2 $\mathrm{mM})$ on relative electrolyte leakage in apricot flower buds under different temperature treatments $\left(-4\right.$ and $\left.+25^{\circ} \mathrm{C}\right)$

Percentage of damage and electrolyte leakage of flower organs is not only influenced by temperature but also is influenced by $S A$ concentration. Under $-4^{\circ} \mathrm{C}$ and without SA application $(0 \mathrm{mM})$, the highest damage symptoms and \% EL were observed. Our results coincide with Rouhani Nia et al. (2011), in apricot flowers. They studied the effect of cold stress on flower organs of some apricot cultivars and reported that $1,+2^{\circ} \mathrm{C}$ didn't damage any flower organs, but decreasing temperature from $+2{ }^{\circ} \mathrm{C}$ to $0^{\circ} \mathrm{C}$ and $-2^{\circ} \mathrm{C}$ cause gradually increased damage. From $-2^{\circ} \mathrm{C}$ to $-4^{\circ} \mathrm{C}$ the highest damage was observed (Rouhani Nia et al., 2011). Among different flower organs, pistil was more sensitive to cold stress. Our results were consistent with results of Rouhani Nia et al. (2011), who reported pistil is more sensitive to cold stress than other apricot flower organs. There is often a good correlation between ion leakage and freezing tolerance (Levitt, 1980). Also, Electrolyte leakage is often used as a parameter for determining tissue damage as the loss of membrane's selective perme-

Tab. 1. Effect of exogenous SA pretreatment $(0,0.5,1$ and $2 \mathrm{mM})$ on damaged flower organs percentage in apricot flower buds under different temperature treatments $\left(-4\right.$ and $\left.+25^{\circ} \mathrm{C}\right)$

\begin{tabular}{|c|c|c|c|c|}
\hline \multicolumn{5}{|c|}{ Treatments } \\
\hline Temperature & SA concentration & Petals & Anthers & Pistil \\
\hline \multirow{4}{*}{$-4^{\circ} \mathrm{C}$} & 0 & $27.20 \mathrm{a}^{\dagger}$ & $33.57 \mathrm{a}$ & $66.88 \mathrm{a}$ \\
\hline & 0.5 & $7.11 \mathrm{de}$ & $8.65 \mathrm{e}$ & $10.83 \mathrm{~cd}$ \\
\hline & 1 & $8.14 \mathrm{de}$ & $9.37 \mathrm{de}$ & $9.95 \mathrm{~cd}$ \\
\hline & 2 & $13.46 \mathrm{c}$ & $15.74 \mathrm{c}$ & $19.44 \mathrm{~b}$ \\
\hline \multirow{4}{*}{$+25^{\circ} \mathrm{C}$} & 0 & $2.81 \mathrm{f}$ & $3.62 \mathrm{f}$ & $5.80 \mathrm{~d}$ \\
\hline & 0.5 & $5.85 e$ & $7.09 \mathrm{e}$ & $9.03 \mathrm{~cd}$ \\
\hline & 1 & $9.71 \mathrm{~d}$ & $12.13 \mathrm{~d}$ & $16.66 \mathrm{bc}$ \\
\hline & 2 & $19.34 \mathrm{~b}$ & $21.94 \mathrm{~b}$ & $24.08 \mathrm{~b}$ \\
\hline \multicolumn{5}{|l|}{ Analysis of variance } \\
\hline Replication & & $10.66^{*+\dagger}$ & $19.64^{*}$ & $10.66^{*}$ \\
\hline Treatment & & $194.65^{* *}$ & $282.06^{* *}$ & $194.65^{* *}$ \\
\hline
\end{tabular}

Note: ${ }^{\dagger}$ Means within each column followed by the same letter $(s)$ are not significantly different at 0.05 probability level according to Duncan multiple range test (DMRT)

${ }_{++*}^{* *}$ and ns indicate significance at $p<0.05, p<0.01$ levels and non-significance, respectively 
ability (Bartoli et al., 1995). In our experiments, the lowest of damage symptoms and EL under cold stress $\left(-4^{\circ} \mathrm{C}\right)$ were observed in $0.5 \mathrm{mM}$ SA treatment and with increasing concentration from 0.5 to 2, damage symptoms and EL were increased. At $25^{\circ} \mathrm{C}$, the lowest of damage symptoms and EL were obtained in application of $0 \mathrm{mM}$ of SA and with increasing concentration from 0 to 2 , these traits were increased. The effect of exogenous SA on the stress tolerance of plants is not always obvious. It depends not only on the applied concentration and the mode of application, but also on the overall state of the plant; developmental stage, oxidative balance of the cells, and acclimation by previous biotic or abiotic stresses (Horvath et al., 2007). Although no similar studies have been done with the work ahead on flower buds of stone fruits, but recent studies show that SA may alleviate chilling injury not only at the whole-plant level but also when only the fruits are treated. When tomato plants were treated with $0.01 \mathrm{mM}$ methyl salicylate and methyl jasmonate, the cold tolerance of the fruits increased (Ding et al., 2002). Higher concentrations ( 0.1 and $0.5 \mathrm{mM})$, however, tended to decrease cold tolerance. Similar results were shown for peaches treated with SA and stored at low temperatures (Wang et al., 2006).

\section{Conclusions}

The beneficial effect of SA pretreatment on protecting apricot flower buds from chilling injury was not observed at any concentration in neither temperature treatment. Based on the present results, SA alleviates the negative effect of cold stress on electrolyte leakage and flower organ damages in apricot cv. 'Shahroudi', depending on the concentration of SA used. Maximum alleviation of cold stress was found with $0.5 \mathrm{mM}$ SA application.

\section{References}

Barranco D, Ruiz N, Gomes M (2005). Frost tolerance of eight olive cultivars. HortScience 40:558-560.

Bartoli CG, Simomtacchi M, Guiamet JJ, Montaldi E, Puntarulo $S$ (1995). Antioxidant enzymes and lipid peroxidation during aging of Chrysanthemum morifolium RAM petals. Plant Sci 104:161-168.

Bergmann HL, Maachelett V, Gerbel B (1994). Increase of stress resistance in crop plants by using phenolic compounds. Acta Hort 381:390-395.

Cao S, Hu Z, Zheng Y, Lu B (2010). Synergistic effect of heat treatment and salicylic acid on alleviating internal browning in cold-stored peach fruit. Postharvest Biol Tec 58:93-97.

Ding CK, Wang CY, Gross KC, Smith DL (2002). Jasmonate and salicylate induce the expression of pathogenesisrelatedprotein genes and increase resistance to chilling injury in tomato fruit. Planta 214:895-901.

Durner EF, Gianfagna TJ (1988). Fall ethephon application increases peach flower bud resistance to low-temperature stress. J Am Soc Hortic Sci 113:404-406.

Ercisli S (2009). Apricot culture in Turkey. Sci Res Essays 4:715719.

Faust M, Suranyi D, Nyujto F (1998). Origin and Dissemination of Apricot. Hort Rev 22:225-266.

Fuchigami LH, Evert RD, Weiser JC (1971). A translocatable cold hardiness promoter. Plant Physiol 47:164-168.

Ganji Moghadam E, Mokhtarian A (2006). Delaying Apricot (cv. 'Shahroudi') Flower Induction by Growth Regulators Application. J Applied Sci 6:266-269.

Gianfagna TJ (1988). Chemical control with ethephon of bud dormancy, cold hardiness and time of bloom in peach trees. Plant Growth Reg. Soc. Am. Quart 17:39-47.

Guo SH, Yang Q, Yang XL Yang, Liu YF, Qi JC, Bi YM (2007). Effects of Salicylic Acid on Cold Resistance during Flowering Period and Fruit Sitting Rate in Apricot. Nordwood Forest Research 25:24-27.

Hodun G, Hodun M, Swiecicki W, Naganowska B, Wolko B (2002). Preliminary evaluation of sour cherry fruitlet susceptibility to late spring frosts. Broad Variation and Precise Characterization Limitation for the Future Proceedings of the XVI. EUCARPIA Genetic Resources Section Workshop, Poznan Poland, 16-20 May 2001, 335-337 p.

Horvath E, Szalai G, Janda T (2007). Induction of abiotic stress tolerance by salicylic acid signaling. J Plant Growth Reg 26:290-300.

Hurtado MA, Romero C, Vilanova S Abbott G, Llácer G, Badenes L (2002). Genetic linkage maps of two apricot cultivars (Prunus armeniaca L.) and mapping of PPV (Sharka) resistance. Theor Appl Genet 105:182-191.

Janda T, Szalai G, Tari I, Páldi E (1999). Hydroponic treatment with salicylic acid decreases the effects of chilling injury in maize (Zea mays L.) plants. Planta 208:175-180.

Kang G, Wang C, Sun G, Wang Z (2003). Salicylic acid changes activities of $\mathrm{H}_{2} \mathrm{O}_{2}$ metabolizing enzymes and increases the chilling tolerance of banana seedlings. Environ Exp Bot 50:9-15.

Kang HM, Saltveit ME (2002). Chilling tolerance of maize, cucumber and rice seedling leaves and roots are differentially affected by salicylic acid. Physiol Plant 115:571-576.

Levitt J (1980). Responses of plants to environmental stress. Academic Press. London.

Lin W, Pliszka K (2001). Blueberry flower spring injury in central Poland. Small Fruits Rev 1:43-49.

Murdoc BA, Ferguson NH (1990). Effects of fall ethephon and gibberellic acid applications on bloom delay, flowering and fruiting of plum. Hortic Sci 25:1110-1110.

Ozturk K, Olmez H, Colak S, Celik B (2006). Effects of potassium nitrate on cold resistance of Cataloglu apricot variety. Acta Hortic 701:713-718.

Promyoua S, Ketsab S, Van Doorn WG (2012). Salicylic acid alleviates chilling injury in anthurium (Anthurium andraeanum L.) flowers. Postharvest Biol Tec 64:104-110. 
66

Raskin I (1992). Role of salicylic-acid in plants. Annu Rev Plant Physiol Plant mol Biol 43:439-463.

Rehder A (1967). Manual of Cultivated Trees and Shrubs. Macmillan. New York.

Rouhani Nia M, Motallebi-Azar A, Davati-Kazemnia H (2011). Effects of cold stress on some Apricot (Prunus armeniaca L.) cultivars in different phonological stages. AAB Bioflux 3:178-183.

Sayyari M, Babalar M, Kalantari S, Serrano M, Valero D (2009). Effect of salicylic acid treatment on reducing chilling injury in stored pomegranates. Postharvest Biol Tec 53:152-154.

Senaratna T, Touchell D, Bunn E, Dixon K (2000). Acetyl salicylic acid (aspirin) and salicylic acid induce multiple stress tolerance in bean and tomato plants. Plant Growth Regul 30:157-161.

Soni SL, Yousif YH (1978). Inducing delay in flowering of apricot with growth-regulators. Indian J Agric Sci 48:197-200.
Tasgin E, Atici O, Nalbantoglu B (2003). Effects of salicylic acid and cold on freezing tolerance in winter wheat leaves. Plant Growth Regul 41:231-236.

Tsonev R (1995). Selection of parental forms of apricot for cold resistance. Rasteniev'dni Nauki 32:183-185.

Van Breusegem F, Vraneva E, Dat JF (2001). The role of active oxygen species in plant signal transduction. Plant Sci 161:405-414.

Vilanova S, Romero C, Abbott AG, Llacer G, Badanes ML (2003). An apricot (Prunus armeniaca L.) F2 progeny linkage map based on SSR and AFLP markers, mapping Plum Pox Virus resistance and self-incompatibility traits. Theor Appl Genet 107:239-247.

Wang L, Chen S, Kong W, Li S, Archbold DD (2006). Salicylic acid pretreatment alleviates chilling injury and affects the antioxidant system and heat shock proteins of peaches during cold storage. Postharvest Biol Tec 41:244-251. 